УДК 316.614.316.662.316.074

\title{
IIIеремет I. I.
}

канд. філос. наук, доцент, доцент кафедри соціології

Харківського національного університету імені В. Н. Каразіна

к. 305, майдан Свободи, 4, м. Харків, 61022, Україна

тел.: (057) 7075405 ; +380506619463

e-mail: s.grebennikova@karazin.ua

DOI: http://dx.doi.org/10.18524/2304-1439.2018.1(30).145405

\section{АО ICTOPIÏ АВТОНОМIÏ УНIBEРСИТЕTIB}

У статті аналізується науковий дискурс автономії університету. Зазначається, що поняття «академічна автономія» розглядається не тільки як символ університетської ідентичності, тісно пов'язаний з розумінням природи університету, його місця в суспільстві, а й як базовий індикатор розвитку загальноєвропейського освітянського та наукового простору, як інструмент практичного вирішення гнучкого управління академічними структурами. Зазначається, що перший університет, який було засновано у Середньовіччі, виник як автономна інституція. Показано, що така форма організації наукового співтовариства продемонструвала свою перевагу, разом з тим така модель університету мала і свої вади.

Автономія університетів Нового часу формувалась в епоху, коли створювались держави-нації. В основу формування університету було закладено ідеї німецьких філософів, які й розпочали теоретичний аналіз поняття «автономія» .

Аналізується доктрина сучасної університетської автономії, яка активно обговорюється вченими. Особливу увагу приділено аналізу характеристики поняття «автономія» в Законі України «Про вищу освіту».

Розглянуто сучасні теоретичні підходи до сутності феномену університетської автономії, показано, що університетська автономія розглядається дослідниками у трьох площинах: академічній, політичній та фінансовій.

Наведено основні класифікації автономії, дається їхня характеристика. Відрізняють академічну, процедурну та субстантивну автономію, сутність якої визначають через класифікацію цього феномену. Інші дослідники виділяють змістовну, процедурну та організаційно-структурну автономію. Виходячи зі світової практики діяльності вузів, виокремлюють ліберальну та центристську моделі університетської автономії. У залежності від характеру взаємовідносин з державою та особливостей фінансування виокремлюють ринкову, директивну та змішану моделі автономії університету.

Ключові слова: автономія, університет, самоорганізація.

Постановка проблеми. Кардинальні зміни в світі на межі XX-XXI ст. охопили всі аспекти його життєдіяльності та актуалізували проблеми освіти як головної умови прогресивного розвитку суспільства. Україна розбудовує національну освіту в умовах суспільства знань з урахуванням як національних особливостей, так і світових тенденцій. Дослідники все більше уваги приділяють університету, визначенню його функцій в сучасних умовах, стратегії його розвитку, темі університетської свободи, нероздільної з 
поняттям академічної автономії. Треба зазначити, що автономію аналізують не тільки як символ університетської ідентичності, тісно пов'язаної 3 розумінням природи університету, його місією в суспільстві, а й як базовий індикатор розвитку загальноєвропейського освітянського та наукового простору, як інструмент практичного вирішення гнучкого управління академічними структурами. Саме автономія університетів стає ключовою для їхнього розвитку, сприяє створенню механізму їі самооновлення, підвищення відповідальності за їхню діяльність з боку колегіальних органів управління, а варіативність дає можливість відбирати та підтримувати найбільш життєздатні форми.

Аналіз досліджень. Російський вчений С. І. Гессен підкреслював, що повнота наукового знання, свобода викладання і навчання, самоврядування характеризують ідеальну сутність університету як осередку наукового знання [1, с. 316]. Автономія стала невід'ємною частиною ідентичності інтелектуалів, близьких до академічного поля. Так Дарріда вважає, що університетська автономія дає можливість утримати інтелектуальну думку від суєти оточуючого світу [2, с. 96-103]. Академічна автономія спирається на правову легітимацію, яка закріплена в деклараціях, законах, нормативних актах. Діючий закон про вищу освіту визначає автономію вишу, гумбольдтівська модель університету закріплена у Всесвітній декларації про вищу освіту для XXI ст. (Париж, 9 жовтня 1998 р., ст. 2, 13): університет має право «користуватися повною академічною свободою та автономією, яка розуміється як комплекс прав та обов'язків, будучи при цьому повністю відповідальним та підзвітним перед суспільством»; «вищим навчальним закладам повинна бути представлена автономія в їх внутрішніх справах, але така автономія повинна супроводжуватись чіткою та транскоректною підзвітністю уряду, парламенту, учням і суспільству в цілому.

Закон України «Про вищу освіту» визначає автономію як «самостійність, незалежність і відповідальність закладу вищої освіти у прийнятті рішень стосовно розвитку академічних свобод, організації освітнього процесу, наукових досліджень, внутрішнього управління, економічної та іншої діяльності, самостійного добору і розстановки кадрів у межах, встановлених цим Законом» .

Якщо ми перейдемо до історичного дискурсу, то знайдемо протилежні думки щодо суті автономії, факту її існування в університетах, навіть іноді саме слово автономія було заборонене.

В різні часи академічна автономія підпадала не тільки під тиск на університети духовної та світської влади, а й ідеологічного втручання тоталітарних режимів. В Україні академічна автономія протягом всієї історії становлення університетської системи стикалася з викликами, які провокували політичний та адміністративний тиск держави. Саме корпоративний устрій університетського життя дав можливість університетам залишатися більш незалежними на фоні інших державних структур.

Метою статті є визначення характеристики автономії університету у сучасному світі. 
Розглядаючи академічну автономію, необхідно звернутися до історії університету. Історично склалося, що університет виник як автономна інституція. Перший університет виник у Болоньї у 1088 році за ініціативи об'єднання викладачів права та їх учнів з місцевих юридичних шкіл, куди поступово для вивчення права з'їжджається молода еліта з усієї Європи. У 1168 році імператор Фрідріх I Барбаросса надав новому утворенню статус університету з відповідними правами та привілеями. Дарована хартія (Authentica Habita) гарантувала Болонському університету незалежність від місцевої влади та господарчу самостійність, тим самим поклавши початок «академічної свободи». Згідно з хартією болонські студенти щорічно обирали ректора і раду студентів, яка, разом з ректором, завідувала управлінням та університетською юрисдикцією. Самі студенти обирали цікаві для них курси та запрошували для їх викладання відповідних професорів терміном на два роки, сплачуючи їм гонорар. Професори зобов'язувалися не викладати ніде, окрім Болоньї. Студенти отримували право подорожувати по всіх країнах імперії, користуючись захистом імені імператора, тобто мали можливість існування поза межами певних країн та їх законів. Судити студентів університету могли лише в Болоньї. Студент сам обирав, хто саме винесе йому вирок. Студентська корпорація мала можливість регулювати ціни на оренду студентського житла та на книжки, визначати курси, що викладатимуться, встановлювати тривалість занять та канікул. Професори також мали свою асоціацію, яка могла вільно екзаменувати студентів та присвоювати докторський ступінь. Тобто університетську автономію можна розглядати як корпоративну, вона відносилася до інституційної організації та самоорганізації академічного та університетського співтовариства. Така форма організації наукового співтовариства продемонструвала свою перевагу: університети систематично розвивали знання, як цього вимагала практика викладання; університети мали можливість займатися чистою теорією; університети забезпечували поколінське відтворення наукових шкіл. Разом з тим така модель університету мала і свої слабкості. Як зазначає Р. Коллінз, «ї̈ методичний характер та бюрократична організація викликали посилюючу спеціалізацію за вже давно знайомими напрямками. Через це найчастіше відбувалося відторгнення нововведень в давно існуючій теорії» [3, с. 36]. Університети потребували зв'язку з зовнішнім світом для виникнення та розвитку нових напрямків думки.

Автономія університетів нового часу формувалася в епоху, коли створювалися держави-нації. Тоді однією із ключових задач університету було забезпечення національно-культурної ідентичності населення, збереження та трансляція національних культурних кодів. Проблема автономії університету теоретично не формулювалась і не була предметом наукового аналізу. Такий аналіз започаткували німецькі ідеалісти (І. Кант, І. Фіхте, Ф. Шеллінг та інші), філософські напрацювання яких передували створенню Берлінського університету. Згідно з їх поглядами, автономія університету витікала з перемоги чистого розуму і була природною за своїм походженням. Так I. Кант визначав університет як вчене співтовариство (зберігачів наук), що має свою автономію, а також як суперечливу структуру. Головну роль 
у пошуку справжнього знання І. Кант відводив філософському факультету, саме тому він, як і університет у цілому не може коритися нікому окрім істини. Здатність судити автономно, тобто вільно (згідно з принципами мислення взагалі), називають розумом. Філософський факультет, оскільки він повинен ручатися за істинність вчень, які він приймає або хоча б допускає, повинен мислитися як вільний, підлеглий тільки законодавству розуму, а не законодавству уряду. Автор моделі Берлінського університету В. Гумбольдт зазначав, що наука повинна бути інституціоналізованою через автономію університетської спільноти. Надання автономії, на думку автора, має захистити науку від церкви, держави та суспільства. Автономія частіше орієнтується на практичну вигоду. Саме держава є зацікавленою в автономії університету задля отримання благ, які привносить тоталізуюча сила науки [4, с. 23-33].

Автономія німецького університету полягала у самостійному формуванні курсів професорами, самостійному обранні курсів для вивчення студентами, у самоврядуванні під правовим державним наглядом самостійною господарською діяльністю, наявності власного суду для розгляду дисциплінарних справ студентів. Тобто автономія немецького університету вже мала теоретичне обгрунтування, яке випливало з автономії пошуку істини, і мислилася в першу чергу як академічна автономія. Берлінський університет економічно і разом з цим політично залежав від держави.

Доктрину сучасної університетської автономії сформулював професор Женевського університету Бріт Ольсон: ідеальний незалежний університет повинен мати свободу у виборі керівника, свободу у виборі моделі управління; свободу у виборі об'єктів наукових досліджень; свободу у виборі студентів; власність та право розпоряджатися нею; свободу у використанні коштів з додаткових джерел.

Швейцарський дослідник P. Стіквех (R. Stichweh) визначає автономію як здатність академічних структур: самостійно приймати рішення стосовно внутрішньої життєдіяльності у певних інституціональних рамках, визначати стратегічні завдання та інституційні наміри, будувати позитивні взаємовідносини з іншими суспільними сферами, які є важливими для подальшого розвитку (наприклад, економіка, політика, громадянське суспільство); брати на себе відповідальність за прийняті рішення та можливі ефекти, що відбиваються на суспільстві. Академічна автономія, на його думку, є досвідом громадянського суспільства, оскільки передбачає наявність аргументованої публічної дискусії, орієнтованої на досягнення розуміння і компромісу.

Р. Абрамов поряд з академічною автономією підкреслює необхідність надання університету політичних свобод, розкриваючи зміст поняття автономії у свободі досліджень і обміну науковими даними, самоорганізації наукового співтовариства, яке виражається у виборності посад, свободі присудження наукових ступенів на основі власної оцінки [5].

Сутність автономії університету в сучасному світі деякі дослідники визначають через класифікації цього феномену. Відрізняють академічну свободу, процедурну та субстантивну автономію, де акаделічна свобода розу- 
міється як свобода вченого у викладанні та дослідженні. Пошук істини та виробництво знання відбувається без побоювання санкцій з боку політичних, релігійних або будь-яких інших інституцій. Процедурна автонолія розуміється як право університету визначати засоби досягнення цілей та програм. Субстантивна автонолія розкривається у самостійності вищого навчального закладу у визначенні його власних цілей і програм.

В іншій класифікації виділяють змістовну автономію, яка розглядається як право університету вводити власні навчальні програми та визначати цілі; процедурну - визначати способи досягнення раніше встановлених пріоритетів, що є частиною національної політики; і організаційно-структурну - право визначати власну академічну структуру.

Університетська автономія іноді розглядається тільки як свобода відбору професорів та студентів, свобода складати навчальний план та визначати стандарти якості освіти; свобода у керуванні фінансами.

Виходячи зі світової практики діяльності вузів, дослідники виділяють ліберальну та центристську моделі університетської автономії. Ліберальна модель характеризується широкою автономією вузів. Роль держави полягає у визначенні стратегії та загальних пріоритетів системи вищої освіти, у формуванні загальної фінансової та академічної політики. Невід’ємною рисою такої моделі автономії виступає делегування значних управлінських повноважень громадським організаціям, які можуть брати на себе різні функції з оцінки якості освітніх програм, керування фінансами тощо. Найважливішу роль відіграють піклувальні ради, що представляють собою зв'язуючий елемент між університетом і суспільством. Університети мають багатоканальне фінансування окрім державної підтримки. Це доходи від грантів, проектів та договорів, платної освіти, благодійних фондів, продажу науково-освітніх послуг.

Центристська модель характеризується тим, що університети є автономними з правової точки зору в навчальній, науково-дослідній, адміністративній та фінансовій діяльності. Держава регулює їхню діяльність законодавчими актами, наказами та інструкціями органів державного управління.

У залежності від характеру взаємовідносин з державою та особливостей фінансування виділяють такі моделі автономії університету: ринкову, директивну та змішану. При ринковій моделі виші юридично автономні і самостійні, для неї характерна значна децентралізація в управлінні, а саме підпорядкування навчальних закладів місцевим, професійним органам управління або комітетам і комісіям; відсутність державної монополії на створення навчальних закладів; різноманітність типів навчальних закладів та їхніх програм.

Для директивної моделі автономії характерно те, що виші управляються державою, фінансове, матеріальне та організаційно-правове керівництво здійснюється у централізованому порядку на трьох адміністративних рівнях: міністерства освіти, відділів освіти, місцевих відділень.

Для змішаної моделі автономії характерне функціонування вузів як федеративної системи з певною автономією, обмеженою законодавчими рамками. 
Висновки. При реалізації соціальної політики виникає проблема виміру академічної автономії, бо відсутні релевантні інструменти оцінки характеристики автономії університетського світу.

Так, наприклад, свобода досліджень та обміну науковими даними, що передбачає свободу вибору тематики досліджень, методів академічної роботи та способів розповсюдження наукових результатів. Ця теза викликає ряд заперечень. По-перше, така свобода самоорганізації наукового співтовариства може призвести до того, що вчені перестануть реагувати на актуальні суспільні запити; по-друге, свобода досліджень також пов'язана 3 фінансуванням, яке все частіше надходить із неакадемічних джерел. Разом з тим треба зазначити, що викладач, за думкою К. Ясперса, сам вирішує свої важливі задачі; він повинен самостійно проводити свої наукові пошуки, включаючи сюди і постановку проблеми, без заборон з боку будь-кого, без сторонніх вказівок. Викладач - зразок для тих, хто вчиться, тільки не школярів, а дорослих, самостійних і відповідальних людей. Його цінність в тому, що він може давати вказівки і можливість брати участь в його особистій інтелектуальній діяльності. Саме за такої умови, коли студенти та викладачі мають спільні інтереси, структуровані не тільки процесом навчання, а й науково-дослідною роботою, організованою за принципом суспільного «проекту», студент набуває не тільки вміння та навички проведення та організації наукового дослідження, але й вчиться адекватно оцінювати рольову реальність, працювати в команді, розвивати відповідальність.

Академічна автономія передбачає право професорсько-викладацького складу самостійно визначати структуру та зміст навчання. Треба зазначити, що ця складова автономії також знаходиться під впливом і держави, i роботодавців, які роблять замовлення на випускників університетів.

На наш погляд, важливою складовою автономії університету є свобода у виборі студентів. На жаль, університет не має такої можливості. Сьогодні дослідники фіксують зміну ставлення студентів до університету, який вони не розглядають як храм науки, а головною метою для них є диплом престижного університету, який може успішно конвертуватися в посадовий чи економічний статус. До університету треба приймати тих, хто бажає самостійно та творчо просуватися до вершин освіти та науки, відносно яких К. Ясперс використовує метафору духовна аристократія. К. Ясперс підкреслює, що «різниця між двома типами представників академічної спільноти, духовно благородним та духовно несвободним індивідом, в тому, що перший день і ніч думає про свою справу та присвячує їй усі свої сили, другий - потребує розділу між роботою і дозвіллям. Перший на свій страх i ризик прокладає свою дорогу, прислуховуючись до таємничого голосу, який управляє ним зсередини, другому потрібне керівництво, потрібна наукова програма, наказ працювати [6, с. 157].

Академічна автономія передбачає колегіальні принципи самоорганізації наукового співтовариства та університету. Це і вибірність посад професора, декана, ректора, і присудження наукових ступенів на підставі колегіальної оцінки роботи. Цей елемент автономії зберігся в більшості академічних 
систем, крім остаточного права присудження наукових ступенів конкретними університетами без затвердження в державних структурах.

Проблема автономії університетів стає ключовою для їхнього розвитку, а діяльність класичного університету як оплоту демократії може стати фактором більш швидкого просування України на шляху формування громадянського суспільства.

\section{Список використаних джерел і літератури}

1. Гессен С. И. Основы педагогики. Введение в прикладную философию / отв. ред. и сост. П. В. Алексеев. М. : Школа-Пресса, 1995.

2. Даррида Ж. Университет глазами питомцев. Отечественные записки. 2003. № 6. С. 96103.

3. Коллинз Р. Четыре социологические традиции. М. : Территория будущего, 2009.

4. Гумбольдт В. Про внутрішню та зовнішню організацію вищих наукових закладів у Берліні. Ідея університету: Антологія / упоряд. М. Зубрицька, Н. Бабалик, З. Рибчинська; відп. ред. М. Зубрицька. Львів: Літопис, 2002. С. 23-33.

5. Абрамов Р. Н. Академическая автономия на службе интеллектуалов. Социологический журнал. 2010. № 3. С. 107-128.

6. Ясперс К. Идея университета / пер. с нем. Т. В. Тягуновой; ред. перевода О. Н. Шпарага; под общ. ред. М. А. Гусаковского. Минск : БГУ, 2006. 159 с. : ил. (Universitas).

7. Про вищу освіту: Закон України. URL: http://zakon3.rada.gov.ua/laws/show/2145-19

\section{References}

1. Hessen, Serhey. 1995. Osnovy pedahohyky: Vvedenye v prykladnuyu fylosofyyu. Moskva: Shkola-Pressa.

2. Derryda, Zhak. 2003. «Unyversytet hlazamy pytomtsev». Otechestvennye zapysky. № 6: 96103.

3. Kollynz, Rŭndall. 2009. Chetyre sotsyolohycheskye tradytsyy. Moskva: Terrytoryya budushcheho.

4. Humboldt, Vilhelm, 2002. «Pro vnutrishnyu ta zovnishnyu orhanizatsiyu vyshchykh naukovykh zakladiv u Berlini». Ideya universytetu: Antolohiya. Uporyadnyky: M. Zubrytska, N. Babalyk, Z. Rybchynska. Vidpovidalnyy redaktor M. Zubrytska. Lviv: Litopys.

5. Abramov, R. 2010. «Akademycheskaya avtonomyya na sluzhbe yntellektualov». Sotsyolohycheskyy zhurnal. № 3: 107-128.

6. Yaspers, Karl. 2006. Ydeya unyversyteta. Perevod s nem. T. V. Tyahunovoy. Red. perevoda O. N. Shparaha. Pod obshch. red. M. A. Husakovskoho. 159 s. Mynsk: BHU (Universitas).

7. Zakon Ukrayiny «Pro osvitu» URL: http://zakon3.rada.gov.ua/laws/show/2145-19

Стаття надійщла до редакиї̈ 12.06.2018 


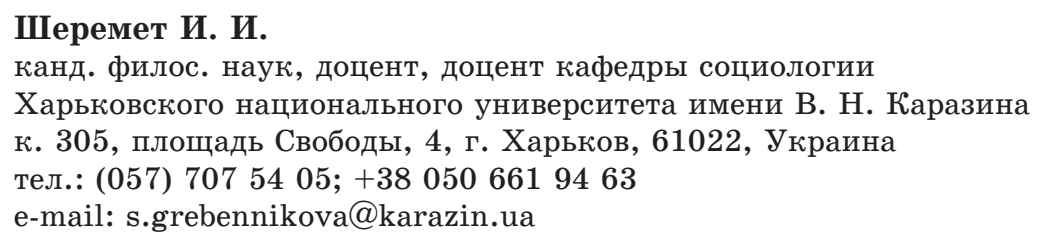

\section{К ИСТОРИИ АВТОНОМИИ УНИВЕРСИТЕТОВ}

\section{Резюме}

В статье анализируется научный дискурс автономии университета. Отмечается, что понятие «академическая автономия» рассматривается не только как символ университетской идентичности, который тесно связан с пониманием природы университета, его места в обществе, но и как базовый индикатор развития общеевропейского образовательного и научного пространства, как инструмент практического решения гибкого управления академическими структурами.

Отмечается, что первый университет, который был основан в Средневековье, возник как автономная организация. Показано, что такая форма организации научного сообщества продемонстрировала свое превосходство, вместе с тем такая модель университета имела и свои недостатки.

Автономия университетов Нового времени формировалась в эпоху, когда создавались государства-нации. В основу формирования университета были заложены идеи немецких философов, которые и начали теоретический анализ понятия «автономия».

Анализируется доктрина современной университетской автономии, которая активно обсуждается учеными. Особое внимание уделено анализу характеристики понятия «автономия» в Законе Украины «О высшем образовании».

Рассмотрены современные теоретические подходы к сущности феномена университетской автономии, показано, что университетская автономия рассматривается исследователями в трех плоскостях: академической, политической и финансовой.

Приведены основные классификации автономии, дана их характеристика. Различают академическую, процедурную и субстантивную автономию, сущность которой определяют через классификацию этого феномена. Другие исследователи выделяют содержательную, процедурную и организационно-структурную автономию. Исходя из мировой практики деятельности вузов, выделяют либеральную и центристскую модели университетской автономии. В зависимости от характера взаимоотношений с государством и особенностей финансирования выделяют рыночную, директивную и смешанную модели автономии университета.

Ключевые слова: автономия, университет, самоорганизация. 


\section{Sheremet I. I.}

PhD in Philosophy, Associate Professor, Associate Professor of the Department of Sociology of V. N. Karazin Kharkiv National University, room 305, Svobody sq., 4, 61022, Kharkiv, Ukraine

(057) 70754 05; +380506619463; e-mail: s.grebennikova@karazin.ua

\section{TO THE HISTORY OF AUTONOMY OF UNIVERSITIES}

\section{Summary}

The article analyzes the scientific discourse of university autonomy. It is noted that the term "academic autonomy" is considered not only as a symbol of university identity that is closely related to understanding of the nature of university, its place in society, but also as a basic indicator of the development of the European educational and scientific areas as an instrument for the practical solution for the flexible management of academic structures.

It is noted that the first university, which was founded in the Middle Ages, arose as an autonomous institution. It is shown that such a form of organization of the scientific community demonstrated its advantages, however, this model of the university had its own disadvantages.

The autonomy of the universities of the New Age was formed in an era when nationstates were created. The foundation of the university was based on the ideas of German philosophers, who began the theoretical analysis of the concept of "autonomy».

The doctrine of modern university autonomy, which is actively discussed by scientists, is analyzed. Particular attention is paid to the analysis of the characteristics of the concept of «autonomy» in Law of Ukraine on Higher Education.

The contemporary theoretical approaches to the essence of the phenomenon of university autonomy are considered, and it is shown that university autonomy is considered by researchers in three areas: academic, political and financial.

The basic classification of autonomy is given as well as their characteristics are described. Academic, procedural and substantive autonomy are distinguished; the essence of autonomy is defined by the classification of this phenomenon. Other researchers make distinctive meaningful, procedural and organizational-structural autonomy. Based on the world practice of the universities, liberal and centrist models of university autonomy are demarcated. Depending on the nature of the relationship with the state and the peculiarities of financing, market, directive and mixed models of university autonomy are characterized.

Key words: autonomy, university, self-organization. 